ISSN 2078-6441. Вісник Львівського університету. Серія географічна. 2013. Випуск 41. С. 303-317. Visnyk of the Lviv University. Series Geography. 2013. Issue 41. P. 303-317.

591.95

\author{
теп н тойко ${ }^{1}$, рин ойнов ${ }^{2}$ \\ 1 нститут екологї рп $m$ кр їни, \\ вул. озельницьк , 4, 79000, м. ввів, кр їн \\ 2 ввівський н ціон льний університет імені вн \\ вул. . орошенк , 41, 79000, м. ввів, кр їн
}

ро н лізов но основні пок зники ст лого розвитку кр їни у світлі рішень с мітів в iо-де- нейро $(1992,2012)$. х р ктеризов но основні спекти екологічної безпеки життєвого середовищ в міст х т сел $\mathrm{x}$ кр їни, які потрібно м ти н ув зі в $р$ зі обгрунтув ння 3 ходів ст лого розвитку. 'ясов но екологічний ст н лісового господ рств т 3 вд ння збереження біологічного й л ндш фтного різном ніття. изн чено превентивні 3 ходи охорони життєвого середовищ в контексті ст лого розвитку.

лючові слов : ст лий розвиток, екологічн безпек, життєве середовище, превентивні з ходи.

б г товіковій історії суспільств ст. м ло н йвищі теми н уково-технічного прогресу, що зумовив кселер цію промислово-індустрі льного потенці лу, нег тивні н слідки якого виявляються у всіх підсистем х біосфери - літосфері, гідросфері, тмосфері, педосфері, біотосфері, соціосфері. йнебезпечнішими н слідк ми техногенного впливу є глоб льне потепління т змін клім ту, руйнув ння озонового ш ру, збіднення біотичного (біологічного) різном ніття. они м ють незворотний х р ктер і створюють 3 грозу для норм льного функціонув ння біосфери як глоб льної соціоекосистеми. ля уникнення глоб льної екологічної кризи, потрібно регулюв ти нтропогенний вплив н підсистеми біосфери.

птиміз цію вз ємодії суспільств і природи, т кож стр тегію ст лого соці льноекономічного розвитку й збереження екологічного б л нсу н пл неті емля розгляд ли н черговій іжн родній конференції, як відбул сь в іо-де- нейро у червні 2012 p. ній взяли уч сть предст вники пон д 100 кр їн світу, у тому числі й кр їни, керівники міждерж вних й неурядових екологічних орг ніз цій. они про н лізув ли 20-річні досягнення кр їн світу щодо ст лого розвитку, оцінили одерж ні результ ти й прог лини в контексті рішень н логічних міжн родних с мітів, які відбулись p ніше в іо-де- нейро (1992) т ог ннесбурзі (2002).

ч сники онференції конст тув ли, що екологічн ситу ція у світі й н д ліє тривожною. гідно з д ними сесвітньої орг ніз ції охорони здоров'я ( ), кількість н селення у 2012 р. досягл семи млрд осіб і з демогр фічними прогноз ми зрост тиме. тже, у сферу виробництв з луч тимуть щор з більшу кількість відновних і невідновних природних ресурсів, зрост тиме нтропогенний вплив н життєве середовище, будуть збільшув тись викиди п рникових г зів, що посилюв тиме небезпеку глоб льного потепління т зміни клім ту.

(C) тойко ., ойнов ., 2013 
д ними іжурядової групи експертів зі змін клім ту, з 1906 по 2008 рр. середня річн темпер тур н пл неті емля зросл н $0,74^{\circ}$. декв тно ст л зменшув тись площ полярного льодовикового щит . 1992 р. середній рівень водного дзерк л вітового оке ну ст в піднім тися зі швидкістю 3,1 мм/рік, що створює з грозу для м лих островів т прибережних територій н суходолі. чені конст тують, що вн слідок ден тур ліз ції природних л ндш фтів н пл неті близько третини біологічних видів $€$ під з грозою зникнення.

ч сники міту емлі-2012 обгрунтув ли глоб льну стр тегію ст лого розвитку, викл дену в підсумковому документі “" йбутнє, якого ми пр гнемо”. я стр тегія спрямов н н вихід суспільств із системних криз - соці льної, економічної, екологічної, продовольчої.

кр їн підпис л документи міжн родних конференцій зі ст лого розвитку т збереження біологічного різном ніття, іотський протокол, т кож інші міждерж вні угоди щодо вирішення екологічних проблем. , незв ж ючи н це, викон ння угод ч сто г льмов не відсутністю дієвих мех нізмів їхньої ре ліз ції т нест чі фін нсув ння. ому низк природоохоронних проблем з лиш ється в кр їні не вирішеною й нині.

ш мет - н ліз екологічної безпеки життєвого середовищ кр їни т обгрунтув ння з ходів ст лого розвитку в контексті ре ліз ції рішень зг д них с мітів

т лий розвиток - 3 порук вирішення соці льно-економічних т екологічних проблем суспільств . т лий розвиток (sustainable development) поклик ний з безпечув ти в системі юдин - рирод т кий соці льно-економічний прогрес суспільств , який би не порушув в екологічний б л нс як в окремих кр їн х, т к і в біосфері в цілому, т кож з безпечув в би потенційні потреби у відновних і невідновних ресурс $\mathrm{x}$ м йбутніх поколінь. $\mathrm{p}$ зі обгрунтув ння стр тегії ст лого розвитку потрібно бр ти до ув ги позитивні т нег тивні н слідки нтропогенного впливу н н вколишне середовище.

юдин , як Homo sapiens, доместифікув л низку видів диких тв рин, окультурил дикі плодові деревні й ч г рникові види, корисні зл ки, городні культури. етодом селекції т генетики вивел сотні нових порід тв рин і сортів культурних рослин, що сприяло підвищенню продуктивності сільського господ рств . нтродукцією людин зб г тил генофонд місцевої флори й ф уни, отже й біологічне різном ніття. озитивну тенденцію у ст вленні юдини до рироди треб вв ж ти 3 кономірною, вон виявлятиметься і в м йбутньому.

оряд з позитивним ст вленням до природного середовищ людин несвідомо, іноді й свідомо вплив л н нього нег тивно. різних континент х перев жно з ї вини зникло 820 видів хребетних і безхребетних тв рин. Г тьох видів тв рин, т ких як стеллерову корову, тур , т рп н , т кож неліт ючих пт хів - мо, дронт , безкрилу г г рку, можн було б доместифікув ти і в н ш ч с вирішув ти проблему з безпечення білк ми зн чної ч стини н селення в бідних кр їн х.

ег тивний вплив позн чився т кож н земельних ресурс х. д ними грунтозн вця . овди (1972), з вини людини у світі утворилося 2 млрд г дев стов них грунтів (бедлендів). умови використ ння цього земельного фонду можн було б нині з безпечити продукт ми х рчув ння близько 2 млрд осіб голодуючого н селення у кр їн $\mathrm{x}$ фрики т зії.

кінця ст. нег тивні н слідки техногенного впливу ст ли виявлятись у всіх скл дових біосфери. ому концепцію ст лого розвитку треб розгляд ти в глоб льному 
вимірі інтегр льно: в соці льному, економічному т екологічному контекст х, беручи до ув ги т кі пріоритетні з с ди:

- $\quad$ свідомлення суспільством обмеженості невідновних (у тому числі й енергетичних ресурсів орг нічного походження) і відновних біологічних ресурсів біосфери, т кож її потенційну ємність щодо техногенного н в нт ження.

- $\quad$ згодження потреби суч сного покоління в природних ресурс х з потреб ми н ступних поколінь для з безпечення прогресу техногенної цивіліз ції.

- $\quad$ ідтрим ння відновлюв ного потенці лу біосфери регенер цією відновних природних ресурсів т зменшенням використ ння невідновних.

- береження біологічного різном ніття біосфери, вз ємозв'язків між втотрофним й гетеротрофним блок ми природних екосистем і педосферою для підтримки еволюційного процесу орг нічного світу.

- $\quad$ згодження існуючого дисб л нсу між демогр фічним процесом у світі т потреб ми з безпечення глоб льної спільноти продовольчими ресурс ми. $\quad$ ке узгодження можливе в р зі обгрунтув ння гум нної концепції регулюв ння приросту н селення.

т лий розвиток повинен грунтув тись н 3 с д х невисн жливого природокористув ння т зб л нсов ності соці льного, економічного й культурного розвитку соціуму.

кий розвиток можливий у вип дку збереження екологічного б л нсу в кожній кр їні т сприятливого для суспільств життєвого середовищ . ід життєвим середовищем м ється н ув зі т сфер н вколишнього середовищ, у якій відбув ється соці льний розвиток суспільств $m$ його економічн й культурн діяльність [18].

кр їні держ вної політики, спрямов ної н втілення в життя принципів ст лого соці льно-економічного т екологічного розвитку, пр ктично нем . е 1997 р. створено ціон льну комісію зі ст лого розвитку при бінеті іністрів кр їни, проте 2003 р. її діяльність припинено. 1999 р. провідні н уковці кр їни з з г льним керівництвом президент кр їни к демік - тон, розробили проект онцепції ст лого розвитку для держ ви. ній визн чили його еколого-ресурсну, економічну, соці льну скл дові, т кож пр вові основи т орг ніз ційні з с ди. дн к, н ж ль, онцепцію т к і не прийняли з конод вчо н держ вному рівні. 2009 р. 3 метою сприяння орг н м викон вчої вл ди в діяльності, що пов'яз н із з безпеченням зб л нсов ного розвитку, створено ціон льну р ду зі ст лого розвитку кр їни. роте цей орг н т кож не ст в центром розроблення т впров дження н ціон льної політики зб л нсов ного розвитку через відсутність пр вових документів.

2011 р. н був чинності кон кр їни “ ро основні з с ди (стр тегію) держ вної екологічної політики до 2020 року” т схв лено ціон льний пл н дій з охорони н вколишнього природного середовищ кр їни н період 2011-2015 pp. і документи м ють в жливу роль у впров дженні іннов ційних принципів покр щ ння екологічного ст ну в кр їні. ухв лені ост нніми рок ми стр тегічні г лузеві документи ст лого розвитку з свідчують зн чний розрив із з г льноприйнятими екологічними пріоритет ми. ому необхідне проведення стр тегічної екологічної оцінки з конів т документів, які прийм є ерховн д щодо економічного розвитку. екологіз ція енергетичної, тр нспортної, сільськогоспод рської, лісогоспод рської т інших промислових г лузей у кр їні м є ст ти пріоритетним з вд нням н н йближчий період.

ит ння концепту льних положень ст лого (зб л нсов ного) розвитку т можливих способів його впров дження в життя у н уковій літер турі порушують досить широко. роблеми узгодження соці льно-економічних т екологічних пит нь для успішного 
розвитку кр їни розгляд ли з поч тку 90-х років ст. окрем, . регобчук [20, 21] дет льно про н лізув в проблеми, які виник ють під ч с переходу кр їни до ст лого розвитку. . униця [4, 23] розглянув можливість ре ліз ції положень зб л нсов ного розвитку з вдяки створенню кологічної конституції емлі як пр вового документ міжн родного м сшт бу. руп вторів сумської еколого-економічної школи н чолі з проф. . ельником $[10,11]$ у публік ціях різних років про н лізув л теоретичні, методичні, прикл дні т філософські спекти впров дження ст лого розвитку.

колективній моногр фії . олубця зі спів в. [8] розглянуто специфіку ст лого розвитку кр їни т необхідність їі вр хув ння в ході підготовки пл нів т кого розвитку в гірських регіон $\mathrm{x}$ рп т. укові основи ведення ст лого водокористув ння у меж $\mathrm{x}$ б сейну річки ністер сформульов но у ст тті . ов льчук [6]. жливість обгрунтув ння еколого-економічних т соці льних спектів під ч с дослідження ризиків виникнення н дзвич йних ситу цій т упр вління ними довел . ронов [2]. всіх зг д них публік ціях простежується думк , що вихід з економічної кризи можливий лише 3 умов з безпечення ощ дливого використ ння й відновлення природних ресурсів т збереження екологічного б л нсу в кр їні.

и з'ясуємо пит ння, які стосуються ст лого розвиту т якості життєвого середовищ в міських гломер ціях, сільських місцевостях, сільському т лісовому господ рств х кр їни з роки, що минули після іжн родного с міту 1992 р.

кологічн безпек життєвого середовищ в міських гломер ціях. міст х кр їни екологічн безпек життєвого середовищ 3 лежить від б г тьох чинників. нтропогенний вплив м є синергідний х р ктер і виявляється у різних форм х - зміні мікроклім ту, з брудненні тмосферного повітря, води й грунтів, шумовому й електром гнітному з брудненні, утворенні зн чної кількості побутових т промислових відходів. відход ми трофічно пов'яз не збільшення популяцій син нтропної ф уни - п цюків сірого (Ratus norvegicus), чорного (R. niger) й інших видів, які сприяють поширенню різних $з$ хворюв нь.

йгірший екологічний ст н життєвого середовищ у великих гломер ціях.

кр їні 68,6 \% н селення прожив є у міст х, з яких п’ять - міст -мільйонери. еликі міст є зн чними спожив ч ми води, енергії т інших ресурсів. прикл д, щороку н селення иєв спожив є близько 646 млн м ${ }^{3}$ свіжої води [17]. йже половин цього об'єму поверт ється в поверхневі води з бруднен сполук ми зоту, н фтопродукт ми, в жкими мет л ми. г льною проблемою всіх міст кр їни є з ст рілі очисні споруди т в рійні к н ліз ційні мережі, які не можуть впор тись зі щор з більшими об'єм ми стічних вод і суч сним з брудненням детергент ми т синтетичними поверхневоктивними речовин ми ( ). ому з з г льної тенденції до зменшення об'ємів стічних вод ост нні 20 років ч стк неочищених вод постійно зрост є (див. т блицю). великих міст х особливі з грози для життєвого середовищ виник ють під ч с зливових бо з тяжних оп дів. ротягом весняно-літнього сезону ост нніх років в рійні з бруднення поверхневих вод стічними к н ліз ційними вод ми виник ли в иєві, ьвові, ніпропетровську, ркові, икол єві т інших міст х. кономічною проблемою $є$ т кож безповоротн втр т води вн слідок технічно недоскон лих, бо з ст рілих водогонів (від 10 до $15 \%$ у середньому по кр їні).

івень з безпечення водними ресурс ми одного жителя кр їни в сім р зів менше середньосвітового. одноч с рівень водоємності н ціон льної економіки в 2,5 р 3 перевищує середньосвітовий рівень. ому з пров дження водоощ дних технологій т 
p ціон ліз ція використ ння води - пріоритетне з вд ння для з безпечення зб л нсов ного розвитку в кр їні.

еякі соці льно-екологічні пок зники розвитку кр їни з 1990-2010 pp.

$[5,12,14,16,17]$

\begin{tabular}{|c|c|c|c|c|c|c|}
\hline \multirow{2}{*}{ сновні пок зники } & \multicolumn{5}{|c|}{ ОКИ } & \multirow{2}{*}{$\begin{array}{c}\text { ин мік } \\
\text { пок зників } \\
\text { 1990-2010 }\end{array}$} \\
\hline & 1990 & 1995 & 2000 & 2005 & 2010 & \\
\hline ількість н селення, млн осіб & 51,9 & 51,1 & 48,9 & 46,9 & 46,0 & $-5,9$ \\
\hline $\begin{array}{l}\text { оефіцієнт н роджув ності, } \\
\text { кількість н роджених н } 1000 \text { осіб }\end{array}$ & 12,6 & 9,6 & 7,8 & 9,0 & 10,8 & $-1,3$ \\
\hline $\begin{array}{l}\text { оефіцієнт смертності, } \\
\text { кількість померлих н } 1000 \text { осіб }\end{array}$ & 12,1 & 15,4 & 15,4 & 16,6 & 15,2 & $+3,1$ \\
\hline икиди в тмосферне повітря, тис. т: & 15549,4 & 7483,5 & 5908,6 & 6615,6 & 6678,0 & $-8871,4$ \\
\hline з них: ст ціон рні джерел & 9439,1 & 5687,0 & 3959,4 & 4464,1 & 4131,6 & $-5307,5$ \\
\hline пересувні джерел & 6110,3 & 1796,5 & 1949,2 & 2151,5 & 2546,4 & $-3563,9$ \\
\hline $\begin{array}{l}\text { бір води з природних водних } \\
\text { об'єктів, млн м }{ }^{3} \\
\end{array}$ & 35615,0 & 25512,0 & 18282,0 & 15083,0 & 14846,0 & - 20769,0 \\
\hline $\begin{array}{l}\text { киди з бруднюв льних речовин у } \\
\text { природні водотоки, млн м }{ }^{3}\end{array}$ & 20261,0 & 14981,0 & 10964,0 & 8900,0 & 8141,0 & $-12120,0$ \\
\hline з них: 3 бруднених & 3199,0 & 4652,0 & 3313,0 & 3444,0 & 1744,0 & $-1455,0$ \\
\hline без очищення & 470,0 & 912,0 & 758,0 & 896,0 & 270,0 & $-200,0$ \\
\hline б’єми н копичених відходів, тис. т & - & - & 26244,1 & 21674,0 & 20587,7 & $-5656,4$ \\
\hline б’єми утворення відходів, тис. т & - & - & 2613,2 & 2411,8 & 1659,8 & $-953,4$ \\
\hline $\begin{array}{l}\text { івень утиліз ції відходів, ч стк від } \\
\text { об'єму утворення, \% }\end{array}$ & - & - & 52,6 & 35,8 & 38,7 & $-13,9$ \\
\hline ісистість території, \% & - & - & 16,0 & 17,3 & 17,8 & $+0,5$ \\
\hline $\begin{array}{l}\text { лощ природно-з повідного фонду } \\
\text { ), тис. г }\end{array}$ & 407,0 & 417,6 & 887,5 & 1104,3 & 1310,5 & $+903,5$ \\
\hline $\begin{array}{l}\text { итр ти н охорону природи, } \\
\text { млн грн }\end{array}$ & - & 2698,5 & 3234,3 & 7089,2 & 11073,5 & $+8375,0$ \\
\hline
\end{tabular}

дним із основних джерел з бруднення довкілля є тр нспортні з соби. икиди з бруднюв льних речовин втомобільним тр нспортом ст новлять близько 40 \% усього обсягу викидів в кр їні, у великих міст х досяг ють 70-90\% з г льного рівня з бруднення. дн 3 причин - пон д $20 \%$ тр нспортних з собів експлу тують 3 перевищенням норм тивів вмісту шкідливих речовин у відпр цьов них г з х. д ними т тистичного щорічник кр їни у 2009 р. н йбільше викидів від втомобільних джерел 3 фіксов ні в иєві - 234 тис. т [17], щільність 3 бруднення ст новил -84 кг н одну особу в рік.

міст $\mathrm{x}$ онецько- ридніпровського регіону головною причиною з бруднення тмосфери є викиди з бруднюв льних речовин великих промислових підприємств.

2009 р. вони ст новили: у ривому озі $-321,6$ тис. т, ріуполі $-283,9$, уг нську 150,4, ніпродзержинську - 110 [16]. ромислові викиди містять у собі п рникові г зи - оксид вуглецю $(\mathrm{CO})$, мет н ( $\left.{ }_{4}\right)$, оксид зоту $\left(\mathrm{N}_{2} \mathrm{O}\right)$, діоксид сірки $\left(\mathrm{SO}_{2}\right)$, феноли, бенз( )пірен, т є небезпечними в р діусі до $100 \mathrm{kM.} 1 \mathrm{~km}^{2}$ площі иєв прип д $€$ близько 350 т шкідливих речовин, викинутих в тмосферне повітря з рік. одібн екологічн ситу ція з фіксов н і в інших великих міст х. 
г лом з 1992 р. $з$ г льний об'єм викидів шкідливих речовин в тмосферне повітря кр їни знизився м йже н половину (див. т блицю, рисунок).

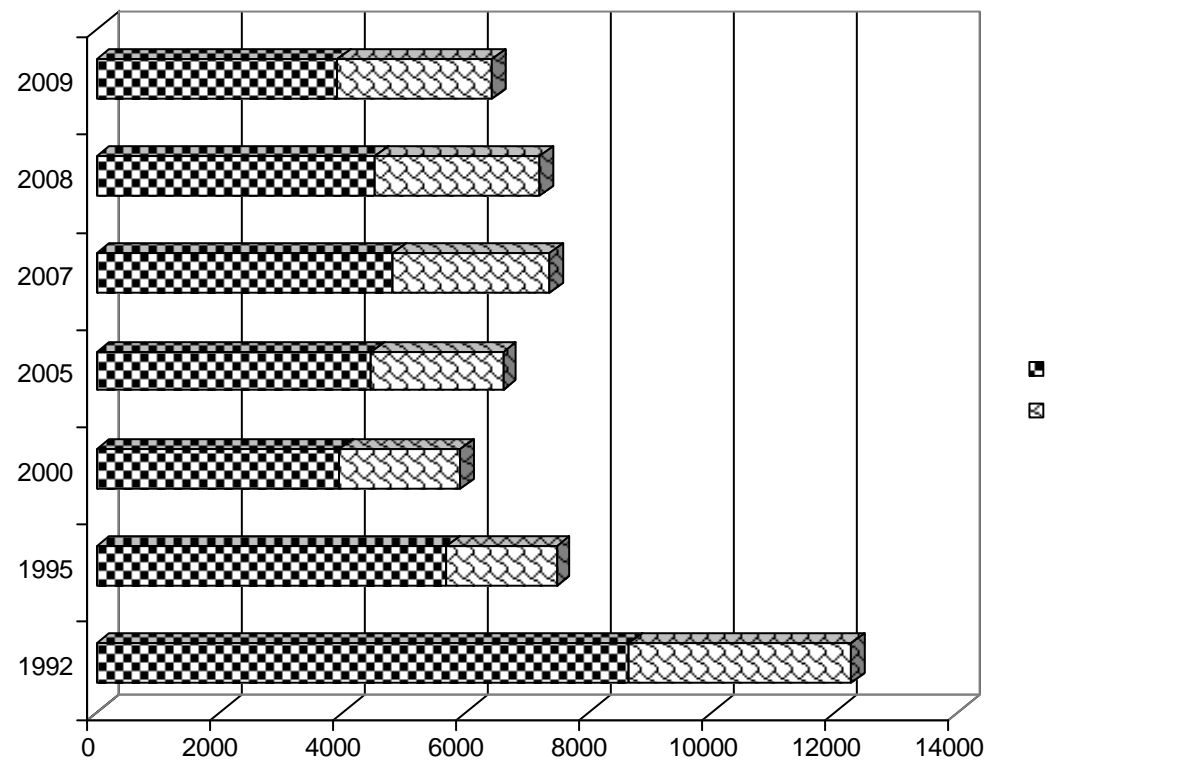

ин мік викидів шкідливих речовин в тмосферне повітря кр їни, тис. т.

т лий розвиток треб розгляд ти як зб л нсов ний розвиток у різних сфер х життєдіяльності людини - соці льній, економічній, екологічній. т блиці под но його головні пок зники впродовж 20-річного періоду.

к 6 чимо 3 н ведених д них, соці льно-екологічн ситу ція в кр їні досить скл дн . очин ючи з 2000 р., спостеріг ється незн чне зрост ння н роджув ності, ле 3 високого рівня смертності приросту н селення не відбув ється. яд пок зників 3 бруднення н вколишнього середовищ знижується. дн к, це зумовлене не впров дженням протиз бруднюючих з ходів, зі скороченням виробництв т економічною кризою ост нніх років. оряд із зменшенням об'ємів утворення відходів, зн чно знизився рівень їх утиліз ції. озитивним є збільшення лісистості в кр їні т витр т н природоохоронну спр ву, зрост ння площі і з ходи сприятимуть збереженню біологічного, фітоценотичного т л ндш фтного різном ніття.

н чний вплив н екологічний ст н довкілля кр їни здійснюють теплові електрост нції ( ). ині викиди у 5-20 р зів перевищують 3 пров джені в вропейському оюзі ст нд рти. ч стку прип д є близько $80 \% 3$ г льних викидів $\mathrm{SO}_{2} \mathrm{~T}$ $25 \% \mathrm{~N}_{2} \mathrm{O}$. ислотні дощі, які вип д ють 3 тмосфери, потр пляють у грунти т водойми й поступово їх 3 кислюють. 2011 р. кр їн ст л членом нергетичного співтов риств вропи і до 2018 р. повинн викон ти взяті н себе зобов'яз ння щодо зменшення викидів до рівня європейських ст нд ртів.

г торічн енергетично-сировинн спеці ліз ція, т кож низький технологічний рівень промисловості кр їни призвели до високих бсолютних пок зників обсягів утворення т н копичення відходів. сховищ х орг нізов ного скл дув ння токсичних 
відходів, які розт шов ні в меж х міст, н території підприємств, ст ном н 2010 р. н копичено 20587,7 тис. т. йбільше їх у порізькій (8 259 тис. т), онецькій (6 331,8), умській (1 855 тис. т) обл стях [16]. івень утиліз ції відходів дуже низький - менше $40 \%$ (див. т блицю).

підст ві н лізу д них д ні ст тистичних щорічників кр їни простежено дивну тенденцію. ороку утворюється близько 2 млн т відходів, ч стк їхньої утиліз ції постійно зменшується, одн к, незв ж ючи н це, з г льний об'єм н копичених відходів зменшується. рім того, з 2000 р. у з г льні обсяги утворених відходів перест ли включ ти відходи четвертого кл су небезпеки т відв ли вуглевидобутку. ому з г льн м с промислових т побутових відходів, сконцентров них у поверхневих сховищ х н території кр їни, зн чно більш і н 2009 р. перевищув л 25 млрд т (з них 5 млрд т токсичних) [17]. тже, н кожного жителя кр їни прип д є пон д 400 т відходів. ріоритетні шляхи зменшення впливу промислових підприємств н довкілля це перехід н льтерн тивні джерел енергії, ощ дливе її використ ння, вторинне використ ння відходів.

зб л нсов ному розвитку урб нізов ного середовищ т підтрим нні якості життєвого середовищ в гоме екологічне зн чення м ють зелені зони міст т приміських територій. ж ль, у зв'язку з інтенсивною розбудовою міст і недотрим нням відповідного з конод вств їхня площ скорочується. е нег тивно позн ч ється н функціонув нні урбоекосистем т здоров'ї міського н селення. ому треб приділити н лежну ув гу збереженню зелених н с джень 3 г льногром дського зн чення.

кологічн безпек життєвого середовищ в сільській місцевості. сільській місцевості в кр їні прожив є 31,4\% н селення [16]. оці льно-економічні т екологічні умови суч сності призвели до того, шо чим ло сіл ст ли депресивними через трудову мігр цію н селення, деякі м лі сел зник ють. і процеси нег тивно позн чилися н демогр фічному ст ні в кр їні, оскільки приріст н селення в сільській місцевості вищий, ніж у міст $\mathrm{x}$.

продовж ост ннього десятиліття н сільськогоспод рських угіддях зниклих сіл простежується поступов рен тур ліз ція грокультурних л ндш фтів. степовій т лісостеповій зон х поширюються угрупов ння бур'янів - мишію (Setarieta), п льч тки (Digitarieta), злинки (Erigeroneta) т низки син нтропних видів. оет пно відновлюються тр в'яні фітоценози - кострицеві (Festuceta), ковилові (Stipeta), мітлицеві (Agrostideta) т інші різнотр вні луки. широколистяно-лісовій зоні поч вся лісоутворюв льний процес (sylvagenesis) - поширюються піонерні деревні види - берез (Betula pendula), терен (Prunus spinosa), види роду верби (Salix), крушини (Frangula) т ін. ей процес добре помітний н місцях $з$ кинутих с дів, ст рих цвинт рів, н тер с х рік, де ще збереглися х р ктерні риси лісового середовищ . ен тур ліз ції л ндш фтів сприяють т кож види лісової ф уни.

ідзн чимо, що т кий спонт нний процес з рост ння грокультурних л ндш фтів з економічної точки зору не 6 ж ний. Г рников рослинність, хоч і виконув тиме певну водо- т грунтоз хисну роль, ле вон не м тиме економічного зн чення. ому потрібно виділити угіддя, прид тні для сільського господ рств т дев стов ні землі, н яких можн створюв ти лісові культури. більшення лісистості в кр їні в жливе як в екологічному, т к і в економічному пл ні.

емельний фонд кр їни - н йцінніший природний ресурс, який м є 3 г льнон ціон льне зн чення. т ном н 1 січня 2011 р. площ сільськогоспод рських земель ст новил 42791,8 тис. г, у тому числі 41576 тис. г сільськогоспод рських угідь. 
цих угідь н ріллю прип д є 32 476,5 тис. г, бо 53,8 \% від з г льної площі кр їни [17]. продовж трив лого грокультурного періоду відбулися суттєві територі льні зміни в структурі земельного фонду. площі 1 028,3 тис. г є землі без рослинного покриву бо ч стково з рослі. е піски, яри, к м'янисті землі т інші неприд тні для землеробств угіддя. лощ відкритих з болочених земель ст новить 979,9 тис. г . ід відкритими промисловими розробк ми, к р'єр ми, ш хт ми є 151,3 тис. г . ціон льне використ ння й збереження земельного фонду повинні бути пріоритетним соці льним, економічним т екологічним з вд нням.

орівняно з іншими держ в ми, в кр їні н йбільш розор ність сільськогоспод рських угідь $-72,5 \%$. е свідчить про екстенсивний х р ктер використ ння земельних ресурсів. високого пок зник розор ності в степовій і лісостеповій природних зон х, у яких лісистість колив ється в меж х 5-10\%, постійною є небезпек ерозійних процесів. підсумку, близько $40 \%$ розор них земель потерп є від ерозії [17]. ерез з бруднення тмосфери т вип д ння кислотних дощів 43,2 \% земельного фонду м є підвищену кислотність грунту.

н слідок недотрим ння екологічних вимог під ч с іриг ційних з ходів, зокрем н длишкового поливу, у степовій зоні простежується з солення грунтів. он д 27 \% меліоров них земель перебув є н різних ст діях з солення [22]. оліссі н прикінці 80-х років ст. поч ли виявлятись нег тивні н слідки осушув льної меліоp ції. ерез 25 років після осушення потужність торфу зменшил сь н 60 см, темпи “с моспр цюв ння торфу” ст новили 2,4 см/рік [4].

емельний фонд кр їни і н д лі використовують нер ціон льно. гідно з дослідженнями . оротун [9], у другій половині ст., упродовж 1967-1996 pp. (40 років) площ орних земель зменшил сь н 3,04 млн г . корочення трив є і нині: 32006 до 2011 рр. площ сільськогоспод рських угідь зменшил сь н 150,8 тис. г [14]. ількість орних земель у розр хунку н одного мешк нця зменшил сь з 1 до 0,7 г .

кологічн необгрунтов ність використ ння земельного фонду т ерозійні процеси спричинили зн чні втр ти гумусу, які ст новлять пон д 20 млн т у рік. ост нні 30 років вміст гумусу в грунт х кр їни зменшився н $30 \%$ [18]. сновні причини цього явищ - суч сн структур посівних площ: м л ч стк земель під одно- т б г торічними тр в ми, які є ст білізув льним чинником грол ндш фтів, т кож збільшення посівів культур (соняшнику, ріп ку), які висн жують грунти. умови недотрим ння н уково обгрунтов них сівозмін вирощув ння т ких культур пов'яз не зі зн чними екологічними ризик ми.

днією 3 х р ктерних озн к н шого століття є економічн глоб ліз ція, як стосується й н шої кр їни. лощ чорноземних грунтів в кр їні ст новить 27,8 млн г (60\% орних земель) [16]. 3 п с ми чорнозему, вон посід є друге місце в світі. вдяки гр рному потенці лу вон м є ре льні можливості збільшув ти виробництво сільськогоспод рської продукції для вирішення світової продовольчої кризи. дн к для цього потрібні з ходи оптиміз ції сільськогоспод рської інфр структури.

огляду н модерніз цію сіл нтропогенний вплив н життєве середовище ст в м сшт бнішим. т н водопост ч ння у сільській місцевості нез довільний. ише четверт ч стин сіл кр їни охоплен центр лізов ними водогон ми питної води [14]. ешт сільського н селення п'є воду з криниць, якість води в яких ч сто н відповід є норм тив м.

скільки в н селених пункт х нем $є$ к н ліз ції, то вн слідок з стосув ння детергентів 3 зн ють з бруднення грунти, підземні т поверхневі води. більшується кількість 
побутових відходів. околицях більшості сіл виникли стихійні сміттєзв лищ , небезпечні в с ніт рно-гігієнічному спекті. о суч сного впливу дод ються нег тивні н слідки господ рюв ння в р дянські ч си. кл ди неприд тних для використ ння пестицидів, більш ч стин яких $є$ в нез довільному ст ні, створюють небезпеку з бруднення грунтів т природних вод. ирішенню цих соці льних і екологічних з вд нь тре$б$ приділити н лежну ув гу.

ур хув нням різних н слідків нтропогенного впливу у сільській місцевості в прогр му ст лого розвитку м лих міст т сіл потрібно включити спеці лізов ні екологічні 3 ходи. об зменшити м сшт би розорюв ння грунтів треб підвищув ти їхню родючість. ля усунення небезпеки ерозійних процесів н схил х доцільно з стосовув ти тер сов не землеробство.

степовій і лісостеповій зон х потрібно приділити н лежну ув гу збереженню мережі полез хисних лісових смуг, суч сн площ яких ст новить пон д 450 тис. г . їхнє створення в повоєнні роки були витр чені величезні м тері льні ресурси. ісосмуги суттєво знижув ли небезпеку суховіїв і сприяли підвищенню урож йності зернових культур. ісля розп ду колгоспів і прив тиз ції земель, лісосмуги з лишились без н лежного догляду і ст ли втр ч ти вл стиве їм з хисне зн чення. ля збереження функціон льного призн чення полез хисних лісосмуг потрібно з безпечити їх охорону. метою збереження родючості грунту н терен $\mathrm{x}$ кр їни т його гумусового горизонту, треб обмежити площу орних земель під грунтовисн жув льними культур ми. світі зрост є попит н екологічно чисті х рчові продукти, тому розвиток землеробств 3 використ нням орг нічних добрив підвищить ефективність сільського господ рств . півдні кр їни в з сушливій зоні під ч с іриг ційних з ходів потрібно дотримув тись екологічних вимог щодо поливу сільськогоспод рських культур.

т н лісового господ рств $\mathbf{T}$ прогр м ст лого розвитку. орівняно з іншими тип ми рослинності, лісові форм ції з вдяки довговічності, скл дній орг нічній структурі в н дземному ярусі т грунті м ють н йв гоміше екологічне зн чення в природному середовищі. д ними іністерств охорони н вколишнього природного середовищ, ст ном н 1.01.2011 р. площ лісів т лісових земель в кр їні ст новил 10 601,1 тис. г , $з$ яких лісовою рослинністю вкрито 9 677,2 тис. г . лісовому фонді числиться 403,4 тис. Г ч г рників т 205,3 тис. Г невкритих лісовою рослинністю угідь.

ротягом історичної доби лісові форм ції з зн ли суттєвих територі льних т ценотичних змін, які нег тивно позн чились н їхньому екологічному ст ні. підст ві дослідження фізико-хімічних озн к лісових грунтів т рхівних м тері лів з'ясов но, що в середньовіччі у суч сних меж х кр їни лісистість ст новил $44 \%$ [1]. ині вон м йже втричі менш і дорівнює лише $17,8 \%$. рп т х у до грокультурний період ліси вкрив ли 90-95\% території, нині лише 50\%. кр їн н лежить до н йменш 3 ліснених кр їн вропи.

ниження лісистості у степовій т лісостеповій зон х нег тивно позн чилося н клім тичному режимі, в рп т х - н гідрологічному ст ні гірських рік. ірськ систем розт шов н в зоні гумідного т євгумідного клім ту, в орг нському т орногірському м сив х вип д є 1400-1600 мм оп дів у рік. меншення лісистості т змін природної ценотичної структури гірських лісів є однією з причин періодичного виникнення к т строфічних повеней. гідно з дослідженнями кр їнського гірського лісівництв , у рп т х, з умов н дмірних оп дів, стиглі букові ліси зд тні з тримув ти 140-160 мм тмосферних оп дів, смерекові - 70-90 мм. ля зменшення небезпеки 
повеней потрібно збільшув ти лісистість у верхів'ях б сейнів иси, ересви, іки, руту, ністр т інших гірських рік, формуючи ліси, близькі до ст більних природних екосистем.

он дпл нові рубки лісу в кр їні, які пр ктикув ли в р дянські ч си, призвели до порушення вікової структури лісів. д ними ержкомлісу, ст ном н 1.01 .2007 р. молоді деревост ни з йм ли $31 \%$ площі держ вного лісового фонду, середньовікові 45 , пристиг ючі - 13, стиглі й перестиглі - $11 \%$. птим льне зн чення стиглих лісів 18-20\% [12]. одібн віков структур лісів спостеріг ється і в рп т х. лощ молодих деревост нів ст новил н 1.01 .2000 р. $33 \%$ держлісфонду, середньовікових 40 , пристиг ючих - 12, стиглих і перестиглих - $15 \%$. ісові екосистеми лише 3 30-40 років зд тні повною мірою виконув ти водоз хисну т клім торегулюв льну функції, тому суч сн віков структур к рп тських лісів ускл днює екологічну ситу цію.

огляду н н слідки нтропогенного впливу н лісовий покрив у прогр му ст лого розвитку лісового господ рств доцільно ввести з ходи, які б сприяли не лише збільшенню лісистості, й поліпшенню екологічної ст більності лісів, отже, і викон нню ними в жливих з хисних т соці льних функцій.

ряд кр їни 2009 р. $з$ твердив ерж вну цільову прогр му н 2010-2015 pp. “ іси

кр їни”, якою передб чено створити 560 тис. г лісів н еродов них і з бруднених землях т в знеліснених б сейн х рік. приятливі грунтово-клім тичні умови в кр їні д ють змогу поступово ре лізув ти цю прогр му. творення нових лісів можливе т кож н місці ч г рникових $з$ ростей, площ яких ст новить 403,4 тис. Г . і з рості виникли вн слідок трив лого п стор льного впливу, лісових пожеж т інших видів нтропогенного впливу й нині не м ють економічного зн чення.

більшення лісистості т поліпшення екологічного ст ну лісів сприятиме оптиміз ції екологічного б л нсу в кр їні, поліпшенню пл нет рного киснево-вуглекислого б л нсу, отже, буде певним внеском у викон ння умов іотського протоколу.

береження біологічного т л ндш фтного різном ніття. н слідок широком сшт бної ден тур ліз ції природних л ндш фтів, техногенного з бруднення довкілля, 3 ост нні десятиріччя й глоб льної зміни клім ту, у світі простежується небезпечний процес збіднення біологічного різном ніття. д ними мерик нських біологів . міт , . ея, . еллев [25], у світі під з грозою зникнення є 23062 види рослин, 3565 видів тв рин. о ервоної книги кр їни з несено 611 видів судинних рослин (13,5\% від боригенної флори) т 542 види хребетних і безхребетних тв рин. тр ту р ритетного генофонду видів флори й ф уни треб розгляд ти не лише в екологоекономічному пл ні. $з$ їхнім зникненням розрив ється певн л нк в екологічному л нцюзі, що може нег тивно позн читись н еволюційному процесі орг нічного світу.

риродн флор кр їни н лічуе 4520 видів судинних рослин, що ст новить $37,5 \%$ флористичного б г тств вропи, де відомо 12,5 тис. видів. ому кр їн м $\epsilon$ в гоме зн чення для збереження біорізном ніття н континенті. йліпше зберегти p ритетний генофонд можн в системі природно-з повідного фонду. ережу з повідних територій створюв ли н підст ві з конів “ ро охорону н вколишнього природного середовищ ” (1991), “ ро природно-з повідний фонд кр їни” (1992), “ ро екологічну мережу кр їни” (2004).

т ном н 1 січня 2011 р. природно-з повідний фонд кр їни н лічув в 7739 об'єктів і територій з г льною площею 3 458,9 тис. г. прибережній кв торії орного моря створено бот нічний 3 к зник площею 402,5 тис. г . ся площ ст новить 5,7 \% від площі кр їни [14]. 
истем охоплює території з г льнодерж вного зн чення: 19 природних з повідників, 4 біосферні з повідники, 47 н ціон льних природних п рків, 307 з к зників, 130 п м'яток природи, 18 бот нічних с дів, 7 зоологічних п рків, 19 дендрологічних п рків, 88 п рків-П м'яток с дово-П ркового мистецтв (усього 641 об'єкт). г льн площ біосферних з повідників т н ціон льних п рків ст новить 1672 тис. г (48\% площі , 2,8\% площі кр їни). ціон льним природним п рк м н д но в постійне користув ння 873,7 тис. г (25\% площі т 1,4\% площі кр їни).

кількістю н ціон льних п рків кр їн випереджує деякі сусідні з рубіжні кр їни, одн к з площею відст є. ому доцільно збільшув ти площу територі льно невеликих н ціон льних природних п рків. землях н ціон льних природних п рків, які н леж ть іншим користув ч м, охоронний режим нез довільний. ому 6 ж но перед ти їхні землі н ціон льним п рк м. іосферні з повідники (резерв ти) поки що не сприяють ст лому розвитку в р йон х їхнього розт шув ння. ому потрібно обгрунтув ти прогр му зрівнов женого розвитку для н селених пунктів, розт шов них н їхній території.

ревентивні $з$ ходи оптиміз ції життєвого середовищ при обгрунтув нні прогр ми ст лого розвитку. творення ціон льної стр тегії ст лого розвитку - 3 вд ння б г торівневе. он повинн бути обгрунтов н для кр їни з г лом, для обл стей, дміністр тивних $\mathrm{p}$ йонів, великих міст, сіл, для в жливих у соці льноекономічному пл ні природних регіонів, які вирізняються певною екологічною т економічною специфікою.

изк н селених пунктів у кр їні нині перебув є в депресивному ст ні. огляду н безробіття у сільській місцевості існує мігр ційний процес, м лі сел зник ють. роки

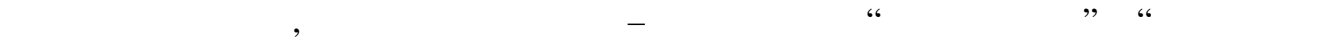
генофонду". е добре усвідомлюв ли керівники колишнього тот літ рного дянського оюзу коли в 1932-33 рок х орг нізув ли в кр їні штучний голод, жертвою якого ст ли мільйони осіб. ому явище депресивності сіл і м лих міст створює з грозу для укр їнського етносу. ля зупинення цього нег тивного процесу, треб створити і поет пно ре лізовув ти ерж вну прогр му покр щення соці льно-економічних умов сіл т м лих міст.

кремі природно-геогр фічні регіони кр їни - рп ти, рим, олісся, оділля й інші - відрізняються екологічними т соці льно-економічними умов ми. ому для кожного $з$ них потрібно обгрунтув ти диференційов ні з ходи екологічної безпеки, охорони життєвого середовищ т ст лого розвитку з ур хув нням їхньої регіон льної специфіки.

кр їн межує із сімом держ в ми, у прикордонній зоні з якими розт шов ні т кі в жливі в екологічному т соці льно-економічному пл ні фізико-геогр фічні регіони, як рп ти, озточчя, олісся. ит ння якості життєвого середовищ $\mathrm{T}$ ст лого розвитку в них 6 ж но вирішув ти н міждерж вному рівні. е стосується й б сейнів тр нскордонних рік - иси, ж , ториці, яну, руту, ністр , хідного угу, ніпр .

кі глоб льні екологічні проблеми, як підтрим ння б л нсу кисню т вуглекислого г зу в тмосфері, з хист озонового горизонту, з хист від з бруднення вод морських екосистем, збереження біологічного різном ніття, теж потрібно вирішув ти н міжн родному рівні.

ля того щоб з безпечити еколого-економічні передумови ст лого розвитку, треб з стосув ти систему превентивних з ходів мініміз ції нег тивних н слідків нтропогенного впливун жжиттєве середовище. промисловості т кими превентивними з хо- 
д ми є з стосув ння льтерн тивних джерел енергії н підприємств х, вторинне використ ння промислових і побутових відходів, рекультив ція порушеного земельного фонду. сільському господ рстві превентивні з ходи поляг ють у збереженні гумусового горизонту в грунт х як природної з поруки їхньої родючості, попередженні з солення грунтів, недопущенні розвитку ерозійних процесів. лісівництві превентивними з ход ми є з стосув ння вибіркового методу експлу т ції лісу, який з безпечув в би його природне відновлення т постійність викон ння водорегулюючої, грунтоз хисної т соці льної функцій. ревентивні з ходи збереження біологічного різном ніття поляг ють у збереженні в природно-з повідному фонді тих екосистем й біотопів, з якими екологічно пов'яз ні зник ючі види флори й ф уни.

б л нсов ний розвиток $m$ оптиміз ція жмиттєвого середовищ вз ємопов'яз ні з вд ння. p зі обгрунтув ння н ціон льної стр тегї $\mathrm{cm}$ лого розвитку треб зв -

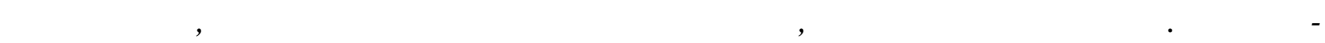
товуючи їх, ми повинні м ти н ув зі не лише вл сні економічні потреби, ле й життєві потреби н ступних поколінь. цьому поляг є мудрість держ вної н ції. цією $n$ р дигмою потрібно керув тись, обгрунтовуючи стр тегію й $m$ ктику ст лого соці льного, економічного й культурного розвитку в держ ві.

тже, м сшт бн й трив л експлу т ція природних ресурсів призвел до з гострення екологічної ситу ції в кр їні т приг льмув л відповідний економічний розвиток. івень н одну особу в держ ві у 2011 р. ст новив $60 \%$ середньосвітового [14]. лизько $15 \%$ території кр їни, з н селенням пон д 10 млн осіб, перебув є в критичному екологічному ст ні. бсяг викидів з бруднюв льних речовин в тмосферне повітря у 2010 р. ст новив 146 кг н кожного мешк нця, що в кільк р зів перевищує т кий пок зник у розвинутих кр їн х світу. рив лість життя в кр їні у 2010 р. ст новил 69,8 року, що зн чно нижче від пок зників розвинутих кр їн. н ліз дин міки кількості н селення кр їни з 2000-2010 рр. свідчить про його щорічні втр ти н рівні близько 370 тис. осіб.

елику з грозу ст новить експортн спеці ліз ція продуктів сільського господ рств . кспортуються зернові культури, не продукти їхньої переробки. зн чній площі вирощуються олійні культури, які висн жують грунти. кр їні, через н дзвич йно високий рівень зношеності основних виробничих з собів, зрост є з гроз техногенних в рій з нег тивними екологічними н слідк ми. креме місце посід ють проблеми, пов'яз ні з в рією н , нег тивні н слідки якої не м ють світових н логів.

індексом екологічного викон ння (Environmental Performance Index), яким вимірюють екологічну скл дову зб л нсов ного розвитку, кр їн у 2010 р. посід л 13-те місце серед $18 \mathrm{kp} \mathrm{їн} \mathrm{хідної} \mathrm{вропи} \mathrm{т} \mathrm{ентр} \mathrm{льної} \mathrm{зії} \mathrm{т} 3$ г льне 87-те місце серед 163 кр їн світу [14].

одноч с, зн чний природно-ресурсний, трудовий, інтелекту льний потенці л в кр їні, н явність чорноземних грунтів, геогр фічне положення в ентр льно- хідній вропі створюють сприятливі передумови для зрост ння економіки й з безпечення ст лого розвитку. ого п р дигму треб розгляд ти в інтегр льному контексті, який охоплює економічну, соці льну, екологічну т культурну сфери суспільств . роцес ст лого розвитку повинен відбув тися в умов х невисн жливого природокористув ння, сприятливого екологічного ст ну т відповідної якості життєвого середовищ кр їни.

прямов ний н оптиміз цію вз ємодії суспільств і природи ст лий розвиток можливий н $б$ зі відповідних юридичних з с д. ому в ході обгрунтув ння його концепції треб приділити н лежну ув гу ухв ленню конкретних з конод вчих ктів прямої дії. 
ля ре ліз ції прогр ми ст лого розвитку потрібні фін нсові ресурси, які в міру його економічного ефекту поступово поверт тимуться в різні г лузі економіки. доскон лення економічних інструментів регулюв ння ресурсокористув ння дозволить збільшити фін нсув ння відновлення т охорони природних ресурсів.

6 л нсов ний розвиток буде успішним, якщо суспільство усвідомить глоб льну небезпеку екологічної кризи для свого існув ння і вв ж тиме своїм етичним т мор льним обов'язком боротись з нею. отрібен відповідний контроль 3 ет п ми ре ліз ції ст лого розвитку з боку як держ ви, т к і гром ди. кий контроль буде можливим, якщо прогр му і з вд ння ст лого розвитку широко оприлюднюв тимуть. ля вступу кр їни в вропейський оюз потрібно, щоб не лише політичн й економічн, ле й екологічн ситу ція т природоохоронне з конод вство відповід ли норм м вропейської спільноти.

\section{СПИСОК ВИКОРИСТАНОЇ ЛІТЕРАТУРИ}

1. кулюк . . мін лісистості кр їни 3 д вніх ч сів до н ших днів / . . кулюк // ісове господ рство, лісов п перов і деревообробн промисловість. - 1972. - № 2. - . 15-19.

2. ронов . . онцепту льні з с ди дослідження ризиків н дзвич йних ситу цій у світлі концепції зб л нсов ного розвитку / . . ронов // кр. геогр. журн. 2009. - № 2. - . 38-43.

3. кологічн онституція емлі. етодологічні з с ди / [з ред. . . униці]. ьвів, 2011. - 440 с.

4. сьянчик . . ффективное использов ние удобрений под многолетние тр вы н осушенных почв х / . . сьянчик // ормопроизводство: проблемы и пути их решения: докл ды н учно-пр ктической конференции. - инск, 1997. - . 100-103.

5. inm 4 . епресивні регіони кр їни: екологічн компонент : моногр фія / . іпт ч. - ьвів, 2008. -288 с.

6. ов льчук. онцепції ст лого водокористув ння і протиповеневого з хисту поселень т господ рських угідь н 3 пл в х річок 6 сейну ністр / . ов льчук // еоретичні т методологічні проблеми суспільної геогр фії : зб. н ук. пр ць н пош ну служ. проф. ьвів. н ц. ун-ту імені в н р нK лег блія. - 2006. . 359-369.

7. ойнов . . нтропогенн тр нсформ ція л ндш фтних систем з хідної ч стини олинського олісся протягом століття : втореф. дис. н здобуття н ук. ступеня к нд. геогр. н ук - ьвів, 1999. - 16 с.

8. онцепту льні з с ди ст лого розвитку гірського регіону / [3 ред. . . олубця]. - ьвів, 2007. - 288 с.

9. оротун . . еогр фія івненської обл сті: рирод . селення. оспод рство. кологія / . . оротун, . . оротун. - івне, 1996. - .36-42.

10. ельник . . снови стійкого розвитку: н вч льний посібник для післядипломної освіти / . . ельник. - уми, 2006. - 383 с.

11. ельник . . ормув ння економіки зн нь, бо принципи орг ніз ції м йбутнього / . . ельник // існик . -2010. - № 6. - . 19-28.

12. ціон льн доповідь про ст н н вколишнього природного середовищ в кр їні у 2007 році. - [ лектронний ресурс]. - ежим доступу: www.menr.gov.ua 
13. рогр м дій “ орядок денний н XXI століття” [пер. 3 нгл.] - . : нтелсфер , 2000. $-360 \mathrm{c}$.

14. роект доповіді кр їни н онференції зі ст лого (зб л нсов ного) розвитку іо+20. - [ лектронний ресурс]. - ., 2012. - 60 с. - ежим доступу: www.ecoleague.net/download.

15. уденко . . оль кр їнських рп т у з безпеченні ст лого (зб л нсов ного) розвитку кр їни / . . уденко // кр. геогр. журн. - 2009. - № 3. - . 23-29.

16. т тистичний збірник “ егіони кр їни” 2011: у 2 ч. / [3 ред. . . с у уленк ]. . : ерж вн служб ст тистики кр їни, 2011.-783 с.

17. т тистичний щорічник кр їни з 2009 рік // ерж вний комітет ст тистики кр їни. - ., 2010. - 567 с.

18. тойко . . уч сні види нтропогенного впливу н життєве середовище / . . тойко, . . ойнов // кр. геогр. журн. - 2012. - № 1. - . 50-57.

19. тойко . . инергідний нтропогенний-техногенний вплив н життєве середовище т зворотні й незворотні можливості подол ння його н слідків / . . тойко // кологія т ноосферологія. -2011. - . 22. - № 3-4. - . 19-27.

20. регобчук. . кологобезпечн економік : льтерн тиви нем є / . . регобчук // існ. . . - 1998. - № 3-4. - . 15-21.

21. регобчук . . онцепція ст лого розвитку для кр їни / . . регобчук // існ. . -2002. - № 2. - . 15-21.

22. руск вецький . . сушені кислі і солонцеві землі / . . руск вецький // емельні ресурси кр їни / [3 ред. . . едведєв і . . ктіонової]. - ., 1998. - . 112-124.

23. униця . . кологічн онституція емлі. дея, концепція, проблеми / . . униця. - ьвів, 2005. - 248 с.

24. униця - і лектик глоб ліз ції в контексті екологічного імпер тиву / . униця, . еменюк, . униця // існик . - 2008. - № 2. - . 8-24.

25. Smith D. M. How much we know about the current extinction rate / D. Smith, R. May, T. Pellew et al. // Trends Ecol. Evol. - 1993. - № 8. - P. 375-378. 


\title{
ECOLOGICAL SECURITY OF VITAL ENVIRONMENT IN UKRAINE AND SUSTAINABLE DEVELOPMENT PROGRAM
}

\author{
Stepan Stoyko $^{1}$, Iryna Koynova ${ }^{2}$ \\ ${ }^{1}$ Institute of Ecology of the Carpathians, National Academy of Sciences of Ukraine, \\ Kozelnytska St., 4, UA - 79000 Lviv, Ukraine \\ ${ }^{2}$ Ivan Franko National University of Lviv, \\ P. Doroshenko St., 41, UA - 79000 Lviv, Ukraine
}

It is analyzed key indicators of sustainable development in Ukraine after the Summit of Rio-deJaneiro in 1992 and data on the ecological safety of vital environment in urban and rural areas. It is disclosed current problems of forest management and conservation of Ukrainian biological and landscape diversity. It is defined preventive measures of protection and conservation of Ukraine vital environment from position of sustainable development.

Key words: sustainable development, ecological safety, vital environment, preventive measures.

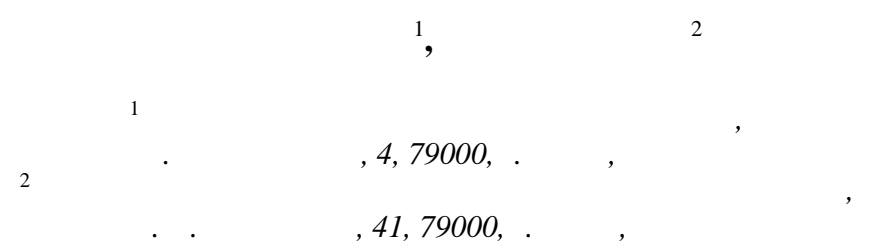

ро н лизиров но вопросы экологической безоп сности жизненной среды в город х и сельской местности, которые необходимо учитыв ть при выборе з д ний для достижения сб л нсиров нного р звития. скрыто современные проблемы ведения лесного хозяйств и охр ны биологического и л ндш фтного $\mathrm{p}$ знообр зия кр ины. дел но н лиз основных пок 3 телей устойчивого р звития кр ины после с ммитов в ио-де- нейро $(1992,2012)$. пределено предупредительные подходы к охр не жизненной среды кр ины с позиций устойчивого p звития.

лючевые слов : устойчивое р звитие, экологическ я безоп сность, жизненн я сред , предупредительные меры. 